\title{
TEHETSÉGBÖL - KIVÁLÓ. \\ KUTATÁS KÖZBEN: A KÜLFÖLDÖN MUNKÁT VÁLLALÓ, FIATAL DIPLOMÁS NŐK ÉLETKEZDÉSI ESÉLYEI
}

\author{
Szerző: \\ Schranz Edit \\ Debreceni Egyetem
}

Szerző e-mail címe:

sedit@t-online.hu

\section{Lektorok:}

Czibere Ibolya

Debreceni Egyetem

Szekeres Melinda

Debreceni Egyetem

Mező Katalin

Debreceni Egyetem

Szilágyi Barnabás

Debreceni Egyetem

Schranz Edit (2015): Tehetségböl - kiváló. Kutatás közben: a külföldön munkát vállaló, fiatal diplomás nők életkezdési esélyei. Különleges Bánásmód, I. évf. 2015/2. szám, 17-35. DOI 10.18458/KB.2015.2.17

\begin{abstract}
Absztrakt
Jelen tanulmány arra keresi a választ, vajon kivételes adottság és kemény tanulás, munka, vagy bátorsággal kevert fiatalos lendület, szerencse, esetleg mindez együtt az, ami lehetövé teszi a 2010-es évek huszonéves, diplomás fiataljai számára, hogy Európa munkaerőpiacán inkább megtalálják a számításaikat. Minta: $n=28$ (22-35 éves) nö. Módszer: félig strukturált interjú. Eredmény: bár minden, általunk készített interjú különösen egyéni életutat mutat, mindegyikröl elmondhatjuk, hogy kemény tanulás, kivételes, tehetséggel párosult szorgalom jellemzi ezeket a fiatalokat. No meg az is, hogy e kis mintában körülbelül 98 százalékuk vágta rá a célzott kérdésre: most úgy látja, soha sem fog visszatérni.
\end{abstract}

Kulcsszavak: tehetség, felsőoktatás, Bologna, diplomás fiatal nők, külföldi munkavállalás, munkaerőpiac

Diszciplínák: szociológia, pszichológia

\footnotetext{
Abstract

EXCELLENT AT BEING TALENTED. RESEARCH: YOUNG GRADUATE WOMEN LIFE STARTING CHANCES OF WORKING ABROAD

This study seeks to determine whether it is exceptional talent and hard work, or courage mixed with young energy and luck, maybe all these together, that makes it possible for young adults with a fresh diploma in the 2010's to find their future in Europe's labor market. Sample: $n=28$ (22-35 years old) women. Method: semi-structured interview. Results: even though all the interviewees are unique, all the participants can be said to have a few things in common; persistent study and exceptional diligence paired with talent. There is, however,
} 
one more thing shared across $98 \%$ of interviewees in our research sample; when asked if they will come back to Hungary, they answered without hesitation that they didn't think they ever would.

Keywords: talent, higher education, Bologna, young women graduates, work abroad, labour market

Disciplines: sociology, psychology

Az értelmiségi, tehetséges fiatalok külföldre távozása, európai, vagy távolabbi munkavállalása jelentős kérdés a gazdasági versenyképesség céljait, a társadalom jövőjét tekintve. Aki elmegy és a végzettségének megfelelő státuszt szerez valamely európai ország munkaerőpiacán, annak jelentősége nemcsak abban van, hogy megfelelö nyelvtudás és szakmai kompetenciák nélkül nem kerülhetett volna a jelenlegi helyére, hanem abban is, hogy az állásért az adott ország helybéli, fiatal diplomás elitjével is versenyre kelt a posztért. Mindez azt feltételezi, hogy a képzése, a munkaerö-piaci felkészülése során olyan tudást, kompetenciát sajátított el, amely felerősítette az egyébként a tanulás folyamatában - mint később látni fogjuk - egyértelműen megmutatkozó tehetséges személyiséget. Függetlenül attól, hogy milyen társadalmi státuszú család gyermekeként került oda, ahol jelenleg tart. A témával sokan foglalkoztak előttünk - igaz, nem egészen az általunk vázolt aspektusban. A tehetséggel, amely az oktatás folyamatában figyelmet érdemel az iskolakultúra, illetve a pszichológia oldaláról - a hazai szerzők közül például - Balogh László, Czeizel Endre, Csermely Péter, Gyarmathy Éva, Mező Ferenc tanulmányait említhetjük. A külföldi szerzők közül Renzulli, Mönks, Gardner nevét említenénk. A magyar fiatalok külföldi munkavállalásával, a migrációval kapcsolatban számos tanulmány látott napvilágot az utóbbi években, például Sík Endre, Róbert Péter, Kolosi Tamás munkái. Azonban az elsők között készül olyan kutatás, amely kis mintán ugyan, de életút-interjúkon keresztül igyekszik feltárni a külföldi munkavállalás és letelepedés okait, nem szakmaspecifikusan. Megjelenik benne a családi háttér, mint a tanulási és érvényesülési hátráltató - és előnyöket megmutató tényező -, s az összehasonlítás az adott szakmák hazai jövedelmi lehetőségeiről és az ebből következő életkezdési lehetőségekről. A vizsgálatban célzottan nem az egészségügyben dolgozók halmazát kívántuk megszólítani, hanem a szerte Európában elhelyezkedett más, vegyes szakmák lehetőségeit kívántuk feltérképezni. A kutatás ugyanakkor igyekszik a mintán keresztül képet adni a kint elhelyezkedő fiatalok élethelyzetéről, integrációjáról, továbblépési, továbbtanulási lehetőségeiről, jövőképéről - és arról, van-e értelme megkérdezni: szándékozik-e hazahozni a tudását? Dolgozatunk első részében tehát igyekszünk képet adni a felsőoktatásban fellelhetö kiegyenlítetlen viszonyokról - amelyet a Bologna-folyamat tükrében vizsgálunk. Majd pedig az elmúlt 1-2 évben elkészült vizsgálatok eredményeit, valamint saját, éppen folyamatban lévő kutatásunk eddigi részeredményeit kívánjuk összefoglalni a külföldön dolgozó magyar fiatalok - elsősorban nők - életkezdési esélyeinek vizsgálatáról.

\section{A tehetségröl}

Kivételesség és társadalmi hasznosság. A számos, tehetségekről szóló elmélet alapján ebben a két szóban foglalhatjuk össze azt a komplexitást, amelyet a talentum, mint jelenség, mai gondolkodásunk értelmében jelenthet. A kivételesség, a tehetség szó tekintetében, magában rejti a kreatív gondolkodást, a megfelelö motiváltságot és ennek eredményeként az átlagon 
felüli eredményt, teljesítményt. Míg Joseph S. Renzulli az átlagon felüli képességet, a feladat iránti elkötelezettséget, valamint a kreativitást emelte be ismertté vált háromkörös modelljébe - amely három dimenziónak közös része adja nézete szerint a tehetséget -, addig Franz J, Mönks, elfogadva Renzulli elméletét, kiegészítette azt a család, az iskola, s a kortárscsoport háttérben szerepet játszó háromszögével, amely szerinte meghatározza a tehetség kibontakozását (Balogh, 2006). Mönks így azt mondja, hogy a tehetség fejlődése, kibontakozása nagymértékben függ a támogatói környezettől. Ennek ismeretében talán nem lehet véletlen, hogy például az angol nyelv három külön szót is használ a tehetség megkülönböztetésére. „Giftedness” - amelynek értelmében Renzulli is vizsgálta a tehetség szót, s amely a potenciális tehetséget, annak ígéretét jelöli. „Talented” - amellyel a már felismert tehetséget hívja az angol, valamint a „genius”, amelyet a kivételes képességekkel megáldott, különleges szellemi képességekkel rendelkező emberekre használ. Mindezekre épülve szoktuk megemlíteni a Czeizel-féle $4 \times 2+1$ faktoros sors talentum-modelljét, amely négy kör közepére helyezi a talentumot, s amely 4 adottságból (értsd örökletességböl) tevődik össze: speciális mentális, általános értelmesség, kreativitás, motiváció. E mögött áll a Mönks-féle háttér és befolyásoló tényező, mint a család, az iskola és a kortárscsoportok, ám megjelenik mellette a +1 faktor, amelyet Czeizel sorsfaktornak nevezett el, mert számol az egyén életében a betegségekkel, a devianciákkal és a korai halálozás lehetőségével is (Czeizel, 2003).

A tehetség tehát a kreativitás, motiváció, átlagon felüli teljesítmény képességével s a környezete támogató hátterével érheti el, hogy helyet találjon a felsőoktatási képzésben, ám mindehhez a megfelelő intelligencia is elengedhetetlen, hiszen a környezethez alkalmazkodás képessége fontos része az önmenedzselésnek. Mindez azonban „hozható, tanulható, tanítható” (Bodná, 2011). A cél valójában az, hogy a hallgató mind jobban tudja magát - a saját érdekeit érvényesíteni, képviselni a munkaerö-piacon, a meglévő és a megszerzett tudás birtokában. Ezzel részben összecseng az Európai Felsőoktatási Térséget létrehozó Bologna-folyamat célkitüzése, amely azon kívül, hogy az európai munkaerö-piachoz illeszkedő képzés megteremtését vette célba, a tömegképzésen belül az elitképzés kereteinek előkészítését is megalkotta (KSH 2009) - amely elitképzésbe a tehetségek, a kiválóan tanuló és tejesítö diákok halmaza éppúgy beletartozik, mint azon fiatalok csoportja, akik a szüleik által megfizetett kiváló iskolák nyomán váltak az elitképzés résztvevőivé. Mindkét halmaz ugyanazon a munkaerőpiacon kíván ringbe szállni a jól fizető állásokért. A kérdés az, mi dönti el, hogy kinek lesz elég tehetsége bejutni és megtartani a pozícióját? Hiszen, ha hihetünk Czeizel Endre és a Mönks-féle háttér fontosságának, akkor hihetünk abban is, hogy a körülmények is közrejátszanak abban, ki, mit ér el, legyenek bár azonos képességeik, ám eltérő feltételeik az induláshoz.

\section{Bolognából - európába}

Mi történik akkor, amikor a tehetségnek nem elég az egyetemi környezete, a szakkollégiumi támogatás? Az Egységes Európai Felsőoktatási Térség létrehozói számára épp az a gondolat játszotta az egyik fö szerepet, hogy a diákok számára az ösztöndíjak elnyerésével még inkább kinyissák a teret - mind a tanulásra, mind az egységes európai munkaerőpiacra (Hrubos, 2012). A 2005-ben, az Egységes Európai Felsőoktatási Térséghez csatlakozó országokban bevezetett bolognai rendszerü képzés létrehozói, kifejezetten a képzési szerkezet megváltoztatásában látták megoldottnak az expanzió, valamint a növekvő munkanélküliség kérdését. A kettő, illetve valójában háromciklusú képzés (alap-, mester- és PhD-képzés - a bolognai rendszer alapján) bevezetésétől várták egyrészt a munkaerö-piaci illeszkedés pozitív változásait, másrészt a tömegképzésen belüli elitképzés kereteinek felállítását - mintegy 
válaszként a felsőoktatási képzés volumenét és szerkezetét mozgató társadalmi, gazdasági, politikai tényezők fejlődést, továbblépést sürgető kérdéseire (Gábor és Szemerszki, 2006).

Azonban mi történik akkor, amikor a Bologna-folyamat deklarált célja - hogy tudniillik Európa munkaerőpiacára képezzük a diákokat - valóban beteljesíti ezt a feladatot, s a tehetséges, jó képességü hallgatók el is mennek? S mint később a saját kutatásunk példáin keresztül látni fogjuk, olykor annak ellenére is, hogy a szülői, támogatói háttér nem feltétlenül ideális a felsőfokú tanulmányok elvégzéséhez. S valójában csak a diákon, a tehetséges tanuló kitartásán, szorgalmán és akaratán múlik, hogy belevág-e a nehézségek ellenére a felsőfokú tanulmányokba. Itt tartjuk fontosnak megjegyezni, hogy alternatív megközelítés szerint az iskolarendszerben felfelé haladva elméletileg csökken a származás hatása. Egyrészt, mert minél idősebb egy diák, annál kevésbé számít a családi háttér - fogalmazza meg az AlwinThornton-féle „életciklus-hipotézisre” építve Róbert Péter (Társadalmi mobilitás, 53.). Másrészt a képzési hierarchia magasabb szintjén a tanulók erősen szelektált csoportját találjuk - szelekciós folyamat hipotézise -, amely csoport esetében a származás jelentősége egyre kisebb. Mint azt a Robert Mare által kidolgozott rendszerből kiolvashatjuk (1981). Mare arra, az oktatási rendszerben meglévő vertikális rendre (hierarchiára) alapozta módszerét, amely szerint a magasabb iskolai szintre lépés feltétele az alacsonyabb szint teljesítése (az általános iskolai bizonyítvány szükséges a középiskolai felvételhez). Így dolgozta ki a feltételes valószínüség elemzési módszerét, amely a származás hatását lépésről lépésre követi az egyes iskolai szinteken (Róbert, 1990).

Az oktatási expanzióval azonban, amikor egyre többen jutnak el a magasabb tanulmányok szintjére, a szelektivitás hatása csökken, a származásé növekszik - Mare ezzel magyarázta, hogy az amerikai társadalomban nem csökkent a származás hatása a magasabb iskolai szinteken (Róbert, 2001, 54.). Hrubos Ildikó tanulmányában szintén az oktatási expanzió hatásaiból indul ki ezzel kapcsolatban, amely nemcsak tényszerủen megváltoztatta a hallgatók társadalmi összetételét a felsőoktatásban, de átalakításra kényszerítette a felsőoktatási intézmények körét is. A társadalmi-gazdasági igények különbözőségei, a megváltozott viszonyok, bizonyos szakokon a hallgatók kegyeiért folytatott és más, erőforrásokért folytatott küzdelem hatására az intézmények is differenciálódtak. A változás egyrészről a különböző funkciók, missziók szerinti, horizontális differenciálódás, másrészről a presztízs szerinti, hierarchikus diverzitás megjelenése felé hatott. (Hrubos, 2012). Azonban ne feledjük, hogy ezek az intézményi változások pusztán következményei az átalakulásnak. Az Egységes Európai Felsőoktatási Térség létrehozásának igazi célja Európa gazdasági és „akadémiai” versenyképességének megőrzése és megerősítése, valamint a hallgatói, majd később a munkaerőpiac fiatal szereplőinek mobilitása volt, és az ma is. A diplomák akadálytalan kölcsönös elismerése folytán, elméletben tehát, a lehetőségek tárházát nyitotta meg a tanulni vágyó és az európai munkaerőpiacon versenybe szálló fiatalok előtt. Igaz, az alap- és mesterképzés közötti ,átmenet” - ahogy Hrubos Ildikó tanulmányában fogalmaz - mint „társadalmi szelekciót tartalmazó lépcső” már igen hamar megmutatta a Bologna-folyamat intézményi, szerkezeti kereteivel létrejött társadalmi egyenlőtlenséget. Ugyanakkor a hallgatói mobilitás Európa országai között is aránytalan. Mivel az utazás szintén az anyagiak függvénye, ám a keleti országok diákjainak a nyugati országokban végzett egyetemi szemeszterek vonzóbbak, mint fordítva, ezért - viszonylag gyorsan - megkezdődött az „agyelszívás” első lépése, amely - Hrubos szerint - nemcsak a kibocsátó országokra, de az európai földrészre nézve is veszélyes lehet a távlatokat tekintve. A fizetős szakok bevezetése pedig egyértelmúen kizáró hatással volt azokra a diákokra, akik nem engedhették meg maguknak, hogy a motivációban esetleg kívánt, de anyagilag elérhetetlen szakokon tanuljanak. Itt utalnánk vissza Mare említett gondolataira, a származás hatásait elemző teóriájára, amely jelen esetben, napjaink Európájában, az eredetileg felállított célok ellenére mégiscsak meghatározza, hogy a bolognai rendszer mely szakán és fokán képes tanulni a 
fiatal - hiszen megfelelöen kondicionált háttérrel - az átjárható kreditrendszer miatt valóban bármely egyetem elérhető. Ugyanakkor fontosnak tartjuk megjegyezni, hogy a későbbiekben vázolt empirikus kutatásunk első eredményei között éppen az tünik ki, hogy az Európa országaiban felvehető diákhitelek rendszere épp a tehetséges fiatalok érvényesülési lehetőségét segíti - mint azt példával is bizonyítani kívánjuk majd. Igaz, ez egyben nemcsak azt a kényelmetlen helyzetet határozza meg, hogy jelentős - több tízezer eurós - adóssággal indul neki egy huszonéves fiatal a jövőjének, hanem azt is, hogy hol kell ahhoz munkát vállalnia, hogy a fizetési kötelezettségét teljesíteni tudja. Igen nagy az esélye annak, hogy nem Magyarországon, hanem valahol... Európában, különben a külföldön felvett diákhitelt, amelyre elkötelezte magát, nem tudná visszafizetni. Európában, Angliában él az a lehetőség, hogy addig nem kell elkezdenie a törlesztést az egyetem felé egy diáknak, amíg egy bizonyos szint fölé nem emelkedik a fizetése (Cambridge). Más országokban nem ilyen megengedő a rendszer, Spanyolországban például a mesterképzésre felvett diákhitelt minden körülmény között el kell kezdeni visszafizetni - függetlenül attól, hogy jól vagy rosszul fizetett állásban tud elhelyezkedni a fiatal. Ilyen helyzetben valóban az átlagnál jobb képességekkel kell rendelkeznie ahhoz egy magyar fiatalnak - megfelelő szülöi háttér nélkül -, hogy ezeket a terheket vállalja az önálló életkezdés küszöbén.

\section{Túlképzettek csapata - vagy mégsem?}

A 2012-es év második felében, a fiatalok körében végzett kutatási adatok - már nem elöször - arra engedtek következetni, hogy a fiatalok „túlképzettek” a magyar munkaerőpiacra. Gazsó Tibor tanulmányában többször is kiemeli ugyanakkor, hogy Magyarországot illetően fontos: nem hozhatjuk összefüggésbe általánosságban a „felülképzettséget”, a diplomás munkanélküliség jelenségével, illetve azzal a ténnyel, hogy a gazdasági válság hatására a diplomások álláskeresési ideje megnőtt. A tanulmány arra hívja fel a figyelmet, hogy a gond egyik része a felsőoktatási kibocsátás szerkezeti problémájából adódik. Mondhatnánk rögtön, hogy „még mindig”, bár a Bologna-folyamat bevezetése óta már 10 év telt el. Gazsó Tibor kutatásai szerint a 2012-ben, a nem dolgozók-nem tanulók csoportjába tartozók több mint egyharmada mindössze általános iskolai végzettséggel rendelkezik. Egynegyedük szakiskolát vagy szakmunkásképzőt végzett. Ezen fiatalok fele a legidősebb vizsgált korcsoportba, a 2529 évesek csoportjába tartozik és a tanulmány szerint 42 százalékuk községi lakos. A számokat elemezve Gazsó Tibor a következőket írja tanulmányában: „,...az adatok világosan jelzik, hogy a magyar társadalomban a gazdasági aktivitás leépülésével perspektíva nélkül maradt, vidéken élö, alacsony iskolai végzettségü csoportok körében töretlenül újratermelödik a halmozottan hátrányos társadalmi helyzet, amelynek egyik fö ismérve a munkához jutás rendkiviuli nehézsége (Gazsó, 2012, 141.).”

A kép különösen akkor disszonáns, ha megnézzük a magyarországi diplomás kutatások adatait (Gazsó, 2012; Magyar Ifjúság Tanulmánykötet, 2012) amelyek szerint ugyanakkor, amíg 2008-ban 3\% volt a felsőfokú diplomával elhelyezkedési nehézségekkel küzdö pályakezdők aránya, addig ez az arány 2012-re 10\%-ra emelkedett. Méghozzá úgy, hogy közben a felsőoktatásban felvett hallgatók száma már a megelöző évektöl csökkenőben volt. Az adatok szerint (Veroszta, 2013; Eurostat, 2012) például a 2012-es évben több mint 20 ezer diákkal kevesebbet vettek fel a felsőoktatásba, mint az azt megelőző két évben. Vagyis a két jelenség, bár teljesen eltérö, társadalmi csoportokról szól, abból a szempontból mégis elgondolkodtató, amennyiben a fiatal generációk perspektíváit erősen egy irányba, az értékvesztés, a kilátástalanság irányába tolja. Az értékvesztés jelenségén gondolkodik el Ságvári Bence „Az átmenetek kora? - A magyar fiatalok társadalomképéről” címü tanulmányában is. Ságvári arra hívja fel a figyelmet, hogy ez a fiatal korosztály a legsérülékenyebb. A sikeres vagy sikertelen munkaerő-piaci integráció a felnőtté válás első 
lépéseinél, az önálló életkezdési körülmények kialakításánál, a korábbi szocializációtól függetlenül is jelentős hatással lehetnek a fiatalok gondolkodására. Beleértve ebbe a társadalommal, gazdasággal, politikával kapcsolatos értékek kialakulását és megszilárdulását. Márpedig ahhoz, hogy az ezen fiatalok által képviselt normák értékek és attitüdök együttese a későbbiekben valódi értéket jelentsenek a társadalom számára, nem mindegy, hogy a korosztály társadalmi integrációjához kötődő „értékszerkezet” milyen keretet ad, hiszen ez határozza meg a későbbiekben a társadalom, a gazdaság és a politika fejlődését.

\section{Bizalomból elégséges}

Ságvári Bence empirikus kutatása szerint a magyarországi fiatalok szemléletét európai uniós összehasonlításban nézve két szembetünő eltérés jellemzi: a normaszegés nemcsak a gazdasági sikerekhez, hanem a mindennapi élethez is szükséges. Fontosnak tartjuk megjegyezni, hogy ez a szemlélet nemcsak a felsőoktatásban tanulókra jellemző, hanem - a tanulmány szerint - általában a magyar fiatalokra. Ez egyértelmü bizonyítéka az értékválságnak és a bizalomvesztésnek. Ha folytatjuk a szerző gondolatsorát és hivatkozunk a tanulmányban leírt elméleti megközelítésekre, ugyancsak elgondolkodtató következtetésekre jutunk: az elméletek szerint ugyanis a bizalom erősíti az egyén közösséghez tartozását, ugyanakkor nem jelenti más csoportok kirekesztését. A bizalom hiánya viszont a társadalmi tőke erodálásához vezet, amelynek végén izoláció, a szerkezetek felbomlása áll. Nem müködnek a kommunikációs csatornák és elindul az emberi kapcsolatok hanyatlása, elindul a rémhírek terjesztése, megerösödnek az elöítéletek, sztereotípiák. Feltehetnénk a kérdést, hogy hogy jön mindez a felsőoktatás és a munkaerőpiac kapcsolatához, de ha a bizalom, mint társadalmi érték oldaláról gondoljuk tovább a fent leírtakat, gyorsan megtaláljuk a választ. Hiszen - mint arra a tanulmány is kitér - a bizalom rendkívül fontos a fennálló társadalmi rend, illetve a társadalom szervezeti müködésének átláthatósága miatt, amelynek egyik legfontosabb eleme a kiszámíthatóság. Ez ad stabilitást a munkahelyeknek és anyagi stabilitást a társadalom tagjainak. A bizalom tehát - állapítja meg írásában Ságvári Bence kihat a gazdasági szemléletre, a társadalom normatív összetartó erőinek jellegzetességeire. Nos, egyből látjuk, hogy ez az a pont, ahol a bizalom kérdése illeszkedik felsőoktatás és a munkaerőpiac kapcsolatához, hiszen nem mindegy, hogy a fiatal felnőttek milyen értékeket fogadnak el. Az értékek alakulását pedig kétséget kizáróan a szülő, a kortárscsoportok és az iskola, pontosabban az oktatás - így a felsőoktatási képzés - képes befolyásolni. Ezt a nem magától alakuló értéksort egészíti ki a fiatal a saját élettapasztalatival. Az így formálódott értékrend az, amely a társadalomban szemléletváltozást képes előidézni. Nem véletlen ahogy Ságvári Bence tanulmányából kitủnik: a szemléletváltás gyakran esik egybe a generációváltással. Ennek a kijelentésnek a tükrében válik érdekessé, hogy tanulmányban idézett Europien Socal Survey egyik eredménye szerint: a fennálló politikai-gazdasági rendszerrel a magyar fiatalok átlagos elégedettsége 52 pont volt, amely európai uniós összehasonlításban nagyon alacsony (legalacsonyabb) indexnek minősül. Az elégedettséget mérő index átlagos értéke a teljes ESS mintában 58, míg a 15-29 éves fiatalok esetében 60 pont volt. E korosztály átlagos értékei 85 (Finnország) és 30 (Görög ország) pont között változtak). Ugyanakkor ez az eredmény nem független a társadalom egészének véleményétől, vagyis ennek megfelelően nincsenek a felmérés szerint generációs különbségek. Mit jelenthet mindez? Talán azt, hogy a mai magyar fiatal generációk éppen olyan „sötétnek” látják a saját jövőjüket, a meglevő tapasztalataikkal, mint a sokat tapasztalt idősebb generációk? Vagy mindössze annyi történik, hogy az idősebbek a szokásosnál jobban hatnak a fiatalok gondolkodására? Mi lehet az oka annak, hogy gondolkodásban, életérzésben, helyzetfelismerésben összeérnek ezen a ponton a generációk Magyarországon? - ahogy Ságvári Bence írja, a fiatalok ,a válság okozta bizonytalansággal „hozzáöregedtek” a 
szüleikhez. A választ, Ságvári a tanulmányában nagyon világosan levezeti: a gazdasági visszaesés illetve stagnálás, valamint a következő évek lassú kilábalása nem ígér gyors, pozitív változásokat a magyar fiatalok életében. Mindez azt jelenti, hogy a közeljövőben a munkaerő-piacra kilépő fiatalok általános generációs élményévé válhat a válságtudat és a bizonytalanság. Akkor is így van ez - írja a tanulmány -, ha időközben jelentősen átszerveződött a felsőoktatás épp annak érdekében, hogy a munkaerőpiac közelebb kerülhessen a felsőoktatási kibocsátáshoz.

Nos, mindezek tükrében talán nem meglepő, hogy a fentebb említett nehézségek, körülmények nem tették/nem teszik feltétlen vonzóvá a Magyarországon elérhető lehetőségeket az életkezdési esélyek szempontjából a fiatal korosztály számára. Különösen a tehetséges, jól tanuló, alkalmazkodásra képes, könnyen váltó fiatalok számára lett vonzó célpont a nagyobb stabilitást, a munkáért megbecsülésként értékelhető, jobb életszínvonallal kecsegtető európai országok - mint azt majd a későbbiekben a saját kutatás alapján látni is fogjuk. Nézzük tehát kik és miért mentek el, hogyan és mennyien találták meg a számításaikat Magyarország határain kívül.

\section{Migráns fiatalok európában: kik mennének, mentek el és miért?}

A The Network és Boston Consulting Group, Európa egyik piacvezető állásportálokat tömörítő szervezete 189 országban készített felmérést a migrációs szándékok lehetséges okairól, 200000 fö megkérdezésével, 2014-ben. Magyarországon 5000 fö került a mintába. A felmérésből kiderült, hogy Magyarország tekintetében a külföldi munkavállalás lehetőségét a megkérdezettek 58 százaléka választaná, ez Európában a 23. helyet jelenti - holtversenyben a svédekkel. A hollandok és a franciák igen vállalkozó szellemüek, 94 százalékuk dolgozna országhatárokon kívül. Az Európán kívüli országok közül azonban Pakisztán gyakorlatilag „kiürülne”, mert a megkérdezettek 97 százaléka menne - ha lehetne. Magyarországról a nők 57 százaléka, a férfiak 43 százaléka keresne más országban állást, ezen válaszadók 30 százaléka gyermek nélküli. De 25 százalékban mozdulnának azok is, akik gyermeket vinnének magukkal illetve párban indulnának útnak. Ugyanakkor elgondolkodtató, hogy azok, akik a mintából a távozásra voksolnának, csaknem 50 százalékban valamilyen felsőfokú diplomával rendelkezők (főiskola, egyetem, Phd-fokozat) és mindössze 26 százalékuk középfokú végzettségü. A távozni szándékozók 83 százaléka Magyarországról az anyagikat jelölte meg. (Csak összehasonlításként, a hollandok 55 százalékban inkább világot látnának és tapasztalatokat gyüjtenének.) A magyaroknak csak 14 százaléka jelölte meg azt indokként a kiköltözésre voksolók közül, hogy már van kint rokon, vagy barát. A legtöbben, 23 százalék Londonba, 13 százalék Münchenbe, 10 százalék Berlinbe menne. Az adatokat összehasonlítva azok körében végzett felméréssel, akik már elmentek Magyarországról, nincs lényeges különbség, 51 százalékban nők - többségében egyedülálló -, illetve igen magas az egyedülálló anyák száma (37 százalék), 49 százalékban férfiak mentek el, közöttük jóval több, 50 százalékuk rendelkezik felsőfokú végzettséggel (29 százalék egyetem - benne a Phd-sok; 26 százalék föiskolai diplomával) rendelkezik. Vagyis a végzettség jelentősen befolyásolja az elindulást. Fontos megemlítenünk, hogy egy 2014-es, a MTA Társadalomtudományi Kutatóközpont Kisebbségkutató Intézete által London és környékén élő migráns magyarok körében készített, 5200 mintán végzett online kérdőíves kutatás eredménye szerint is az látszik megalapozottnak, hogy téves az a nézet, amely szerint az alacsony végzettségüek mentek „szerencsét próbálni, takarítani” Angliába. A válaszadók 53, 2 százaléka ugyanis felsőfokú, vagy posztgraduális végzettségü. Átlag életkoruk 33 év (25-40 év közöttiek). Vagyis az igaz, hogy a munka szempontjából legterhelhetőbb, fiatal pályakezdő vagy már tapasztalt diplomások mentek el, tömegével. A kivándoroltak csaknem 14 százaléka a munkanélküliség elöl, 70 százalékuk a munkájuk megbecsülését kifejező magasabb bér és 
jobb életszínvonal reményében. A megkérdezettek háromnegyede, több mint 70 százalék így hát soha nem térne vissza - a megadott válaszok szerint, de legalábbis a következő öt évben biztosan nem, 20 százalékuk néhány év múlva esetleg, s mindössze 6 százalékuk nyilatkozott úgy, hogy egy éven beül, hazatérne.

Visszatérve az NBC Group adatfelvételére lényeges, hogy célországok szerint Magyarországról a választott országok sorrendje Németország, Svájc és Ausztria, az Egyesült Államok, s csak ezek után következik az Egyesült Királyság. A külföldön élő magyarok közül azonban nem mindegyikük van állásban (egyharmad hozzátartozó, vagy épp állást keres a felmérés szerint), 6 százalékuk vezet valamilyen vállalkozást és 55 százalékuk alkalmazott. (lásd: 1. ábra)

1. ábra: Külföldön élö magyarok foglalkozás szerinti megoszlása (forrás: NBC Group adatfelvétel 2014, saját ábra)

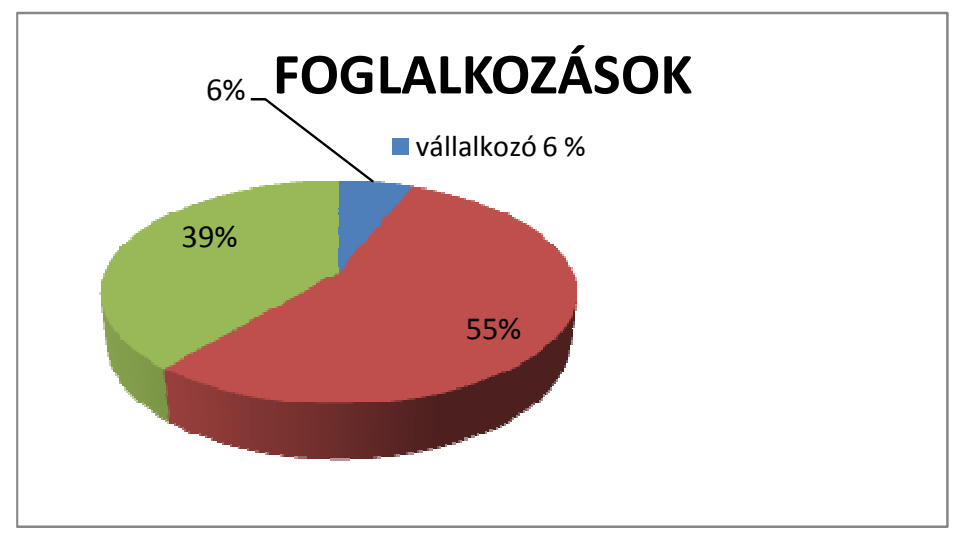

A legtöbben az iparban vagy a technológiában, médiában, telekom-cégeknél állnak alkalmazásban (32 százalék), de sokan dolgoznak a szolgáltatói iparágban is (12 százalék) és kevesebben az egészségügyben (7 százalék - lásd: 2. ábra).

2. ábra: A külföldön alkalmazásban álló magyarok elhelyezkedése - ágazati szektorok szerint (forrás: NBC Group adatfelvétel 2014, saját ábra)
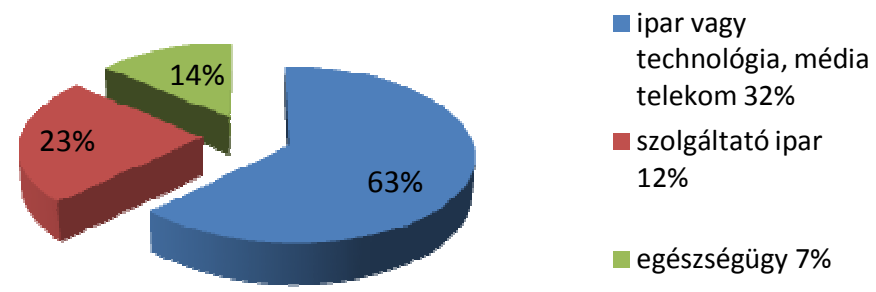
A legtöbben szakmunkásként dolgoznak (közel 30 százalék), a többiek irodai munkát (22 százalék) vagy kétkezi munkát látnak el (15 százalék), illetve alsó vezetői munkakörben vannak. Körülbelül 5 százalékuk helyezkedik el a presztízs piramis csúcsán, mint felső vezető - a felmérés adatai szerint (lásd: 3. ábra).

3. ábra: A külföldön élö magyarok különbözö munkakörei (forrás: NBC Group adatfelvétel 2014 (saját ábra)

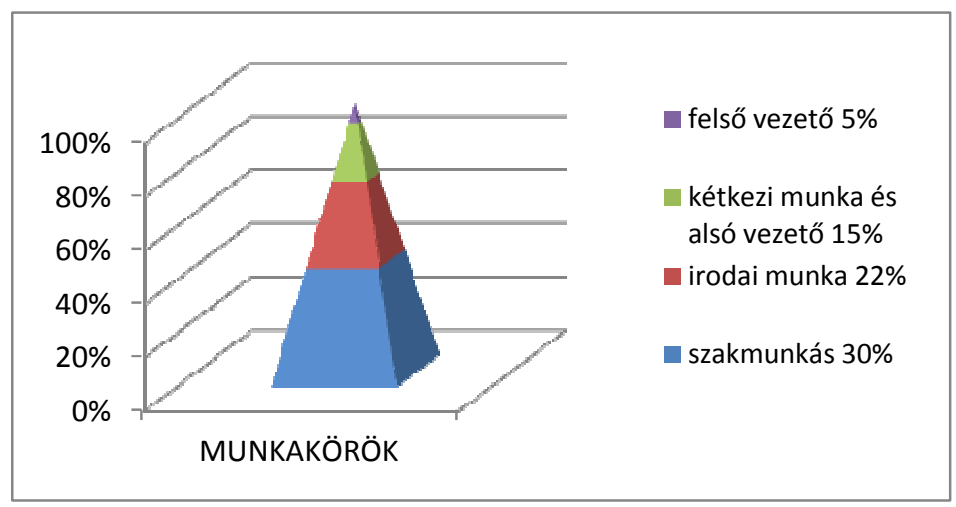

\section{Itthonról másképp látszik}

Annak tükrében, hogy mindkét csoport a már külföldön munkát vállalók és az elmenni szándékozók között is magasabb a nők aránya, mint a férfiaké, nem fedi egy másik, Magyarországon végzett kutatás eredményét. A Magyar Ifjúság 2012 tanulmánykötet szerzöinek felmérése szerint ugyanis, amely kutatás 8000 fös mintán kérdezte meg a 15-29 éves korú magyar fiatalokat, a nők kisebb arányban voksolnak a kiköltözés mellett, mint a férfiak. Különbség van a diplomás és szakképzett fiatalok migrációs hajlandóságában is. A tanulmánykötet szerint utóbbiak inkább kipróbálnák magukat külföldön, miközben a fenti számok azt mutatják, hogy a diplomások jóval nagyobb arányban hagyták és hagynák el az országot, mint a szakmával, középfokú végzettséggel rendelkezők. Itthonról úgy látszik, hogy a diplomások esetén, az „inkább itthon boldogulnék” effektushoz hozzájárul a nem feltétlen megfelelő nyelvtudás, ami nélkül a diplomával kompatibilis - fehér galléros - állás megszerzése nehézségekbe ütközik. Az ifjúsági kutatás - de a 2014-es Eurostat-vizsgálat is azt az eredményt hozta, hogy szignifikáns kapcsolat mutatható ki az idegennyelvtudás és a mobilitási, migrációs hajlandóság között. Az idegen nyelvet nem beszélők 45 százaléka nem tervezi a külföldi munkavállalást, 40 százaléka vállalná az elindulást. Míg a korábban külföldön tanultak populációjából 71 százalék menne, ha lehetősége lenne rá, a külföldet megjárt hallgatók nagyobb hajlandósággal képzelik el a jövőjüket külföldi munkahelyeken. Erre utalt egyébként „A hallgatói mobilitás esete a Bolognai folyamattal" címü tanulmányában Ulrich Teichler is. Eltérő a migrációs hajlandóság azonban az ország különböző területein a fiatalok körében. Régiós összehasonlításban a közép-magyarországi régiót leszámítva - ahol a jobb lehetőségek miatt kisebb mértékben terveznek külföldre menni a fiatalok $(36 \%)$-, országosan gyakorlatilag jóval 40 százalék fölött mennének ugyanakkor, sőt egyes keleti területeken 50 százalék fölötti az arány, fejlettségtől, településtől függően. De befolyásoló tényező a gazdaságilag aktív/passzív térségek helyzetén kívül a család vagy az egyén anyagi helyzete, illetve a családban levő kiskorú gyermekek száma (több gyerekkel kevésbé indulnának el - Ruff, 2013). S míg a 15-19 éveseket visszatartaná az információhiány, addig a felsőoktatásba járók esetén ez a helyzet nem releváns, így számukra 
a visszatartó erő inkább a családi, baráti kapcsolatok erőssége. A Magyar Ifjúság 2012 tanulmánykötet adatai szerint a Magyarországról kivándorló migránsok Németországba, Ausztriába és Nagy-Britanniába mennek nagyobb arányban, ez egybecseng a fent említett NBC Group által készített felmérés adataival, de gyakorlatilag szinte az összes ország célállomás, ahol a gazdasági „gravitáció” elve müködni látszik. Legnagyobb mértékben a 2534, illetve a 34-44 éves korosztály indult el az elmúlt években Nyugat-Európába. Azonban az empirikus adatok szerint Angliában a kifejezetten fiatalabb korosztály (25-29) próbált szerencsét, míg az akár 40, sőt, 50 fölöttiek nagyobb számban Németországban is megtalálhatóak (Ruff, 2013). Mindenesetre tény, hogy az aktív korúak nagyszámú (becslések szerint többszázezres) kivándorlása az elmúlt években nemcsak demográfiailag okoz majd gondot, ahogy már említettük, hanem hosszú távon gazdaságilag is.

A mobilitási attitüdök vizsgálatának elemzését olvasva két jelenség tünik fel, (1) a megkérdezettek több mint fele elhagyná Magyarországot (53\%), ami nagyon jelentős szám, s a fent említett vizsgálat is hasonló eredményt mutatott, (2) a fiatalok 12 százaléka bizonytalan abban, hogy mennyi időre is lenne érdemes külföldre távozni, rövidebben, évekre, vagy végleg. Ugyanakkor tendenciaszerüen látszik, hogy az életkor elörehaladtával egyre kevésbé vonzó a külföldi munkavállalás, míg a 15-19 évesek 55 százaléka menne, addig a 25-29 éveseknél ez az arány 44 százalék (Ruff, 2013). Hiszen nem mindegy, hogy karrierépítés vagy „menekülés” áll a külföldi munkavállalás hátterében. A mintában szereplők közül a rendezettebb családi háttérrel (stabil partner, megfelelő körülmények) kevésbé lennének hajlandóak elmenni, mint a rendezetlenebb háttérrel rendelkezők (pl. gyermektelen elváltak, egyedülállók) (Ruff, 2013). Ez az eredmény is egybecseng, ahogy láttuk fentebb, a már külföldre távozottak körében mért eredménnyel.

Az a fenti adatokból egyértelmüen kitünik, hogy a fiatalok számára a külföldi munkavállalás legföbb oka a jobb megélhetés, amely a szaktudással, ám leginkább a diplomával rendelkező, főként női munkavállalókat szívja el Magyarországról.

\section{Kutatás közben}

A tanulmány utolsó fejezetében folyamatban lévő kutatásunk első részeredményeit kívánjuk bemutatni. Vizsgálatunk a 22-35 év közötti diplomás fiatalokra, elsősorban nőkre terjed ki. Hipotézisünk szerint a fenti kutatásokban szereplő anyagi előnyök mellett a fiatalok elvándorlását azok a külsö-belsö tényezök is motiválják, amelyek miatt e tehetséges (a mintában szereplö), nyitott gondolkodású és lelkületü fiatalok úgy érzik, nem nyílnak meg az általuk elvárt mértékben a kapuk Magyarországon. Sem a munkaerőpiacon, sem a korosztály életfeladatai szempontjából fontos állomásainak szükségszerü megvalósításában - értve ez alatt a megfelelő, motiváló első munkahely megszerzését; az előrelépési lehetőségeket; a külső-belső stabilitás megélését a későbbi otthonteremtésre, családalapításra. S közrejátszik ebben a negatívnak, vagy inkább keserünek nevezhetö érzésben az a „tünet”, amelyet úgy fogalmazhatnánk meg, hogy: a fiatalok által a családból hozott elsödleges értékek (viselkedési szabályok, törvények betartása, tisztelet) devalválódása, a családon kívüli, elsösorban munkahelyi, másodsorban lazább kapcsolati hálózati körben tapasztalt viselkedési és értékpreferencia deficit miatt. Az elkészült interjúk tükrében úgy is fogalmazhatunk, hogy a megrekedtnek tünő gazdasági és közösségi viszonyok azok, amelyek miatt a fiatal korosztály, többségük egy vagy akár két diplomával a zsebében elindul, hogy olyan helyen használja fel az erejét, a tudását és a tehetségét, ahol a megbecsülést is lehetősége lehet megkapni a befektetett energiákért - hangsúlyozottan nem pusztán anyagi szempontból. Így ha nehezebbnek is tünik egy lényegesen nagyobb piacon megméretni magukat, valóságosabb esélyt látnak arra, hogy a kemény munkának (tanulásnak, a beilleszkedési kényelmetlenségeknek, a heti 50-60 órás effektív munkavégzésnek) meglehet a valódi gyümölcse, mert 
általuk preferált - vagy elfogadható, müködő játékszabályokhoz kell alkalmazkodniuk. Nem kell szembenézniük az amúgy is kiszámíthatatlan gazdasági folyamatok diktálta munkaerőpiac mellett egyéb váratlan, tölük független folyamtokkal, amelyek szintén hatással lennének az életritmusuk szerint betölteni kívánt feladatok teljesítésére. S mint a mintánkból hamarosan látni fogjuk, az a döntés, hogy az életfeladat-szerüen tanulással, felsőoktatási tanulmányokkal töltött idő alatt elmegy-e a húszas évei elején járó fiatal huzamosabb időre külföldre - a későbbi európai munkavállalás reményében nem minden esetben korrelál a stabil (szülői) anyagi háttér jelenlétével. Sokkal inkább összefügg az egyén felelősségtudatával, a célok elérésébe vetett hit fiatalos, még akadályokat nem ismerő - vagy épp már megszokott - motiváló erejével, a kitartással, a kreativitással, valamint azokkal a kognitív képességekkel, amelyek miatt az egyén bármely tanulmányi környezetben a kiválóak között lehet.

\section{A célcsoport mintavétele}

E tanulmány elkészítéséig 28 olyan, Magyarországon felnőtt, 18 éves koráig itthon élö, 22 35 éves, diplomás (Bsc, Msc) fiatallal készítettünk félig strukturált interjúkat, akik már évek óta külföldön élnek és dolgoznak, vagy épp állásváltás, kismama-státusz közben vannak, de mindenképpen abban az országban, ahol jelenleg élnek. A statisztika - ahogy fentebb írtuk is - általában a fiatal korosztályt 29 éves kornál lezárja. Azonban úgy véltük, figyelembe kell venni az általunk vizsgálni kívánt korosztálynál azokat a tényezőket, amelyek már egy jó ideje formálják a gondolkodást ezen a téren. Így a későbbre tolódott családalapítási tendenciák, a későbbi házasságkötési és gyermekvállalási kedv (Utasi, 2012), amely szerte Európára jellemző, valamint a fiatalok hosszabb útkeresési időszaka, amelyhez hozzájárul a növekvő fiatal munkanélküliek száma - mint fentebb már jeleztük a diplomásoké is Magyarországon.

Az eddig elkészült interjúk hólabda technika segítségével, szakértöi mintavétellel jöhettek létre, az ország bármely pontjáról elszármazott fiatalokat tekintve. Bár kutatásunk kezdetén többirányú próbálkozásokat tettünk azért, hogy ismeretlenül a facebook, mint modern technikai eszköz segítségével teremtsünk kapcsolatot például Londonban és környékén élö magyar fiatalokkal, a technika először nem akart beindulni. Erős volt a bizalmatlanság. Másnak tünt ugyanis egy személytelen kérdöív kitöltése - erre vállalkoztak volna leginkább, többen is - és más beszélgetni, véleményt mondani, személyes történeteket mesélni - úgy is, hogy közben garanciaként jelöltük meg a válaszadók anonymitását. Ennek a láncolatnak az elindítása végül szintén ismerősök - egyetemi közegből elindult csatornákon keresztül sikerült. Így a referenciák oda-vissza müködésével szépen lassan, estéröl estére megnyíltak a kapuk és ugyancsak a modern technika segítségével létrejöhettek az eddigi skype-interjúk. A technika a multinacionális cégek globális világában nem ismeretlen, a fiatalok hozzászokhattak a skype-on keresztüli HR-interjúkhoz egy-egy állás pályázatával összefüggésben, de alkalmazzák már nyelviskolák is, nem interjúkészítés, hanem oktatás céljából. A hang rögzítését, a szöveg szószerinti leirata miatt skype - recorder program használatával oldottuk meg. Megfigyeltük továbbá, hogy bár a hólabda-technika és a baráti kapcsolatok segítségével országokat és több ezer kilométereket ugrottunk át estéröl estére, vagy épp estéről reggelre, hiszen egyik nap Berlinben, másik nap Provance-ban, majd Svájcban, Münchenben vagy Londonban élő fiatallal készítettük a strukturált interjút, a megkeresések tükrében a válaszadási hajlandóság a német nyelvterületen élők körében mérhetően nagyobb volt. Ennek egyik lehetséges okára a későbbiekben igyekszünk részletesen kitérni.

A kutatás során nem kívántuk foglalkozni azonban a Magyarországról az egészségügyi szakmát képviselő kivándorlókkal, egyrészt, mert az ő esetük egy külön halmazt képez és más 
társadalmi gondokat is feszeget. Valamint azért sem, mert az orvosképzés osztatlan képzésben zajlik, így semmiképpen sem adott volna alapot a későbbiekben az alap- és mesterszakokat végzettek összehasonlítására. Kutatásunk során a továbbiakban is az elvándorlási motiváció, valamint az integráció és a jövőbeni kilátások állnak a középpontban. Keressük a válaszokat arra, hogy diplomájuknak megfelelő állásokban helyezkedtek-e el, mennyiben számított bele a külföldi munkavállalási döntésükbe az egyetem alatt az időszakos tanulmányi célú mozgás (Erasmus, Campus Hungary vagy egyéb ösztöndíjak). Ahogy már említettük, a kutatáshoz félig strukturált interjúkkal kívántuk elkészíteni beszélgetéseket. 4 nagy egységből álló kérdéskört állítottunk össze, amelynek első része a demográfiai adatok felvételét tette/teszi lehetővé, a második egység az elindulás előtti családi, kapcsolati hátteret és hálót kívánta feltárni, a harmadik a jelen helyzetet, valamint a beilleszkedés, integráció elemeit és lehetőségeit kívánta nagyító alá venni és végül a jövőbeni tervek kérdéssora zárja a beszélgetést. Menet közben azonban elrejtettünk a kérdéssorok között úgynevezett „lelkiállapotot” feltáró kérdéseket, illetve a kérdéssor legvégén az egyén személyiségére utaló kérdéseket állítottunk össze. Ez utóbbiak azok a válaszok, amelyeket összesítve már e tanulmányban is meg tudjuk rajzolni az eddig megkérdezett fiatalok személyiségjegyeit, azokat, amelyek nagy valószínüséggel közös jellemzőnek tekinthetőek. S feltehetően szerepet játszhatnak abban, hogy ezek a diplomás fiatalok az adott szituációban, a külföldi munkavállalás mellett döntöttek. Az elkészült interjúkat 2015 októberében készítettük és a következő hetekben folyamatosan rögzítjük a várhatóan újabb 20 interjút, amelyekből a későbbi összehasonlítás reményében 10-15 interjú a diplomával nem rendelkező, 35 év alatti fiatalokkal készül - bárhol Európában.

\section{Demográfiai adatok}

Az eddig elkészített 28 interjú válaszadói az ország különböző területeiről indultak útnak. Közel felük a fővárosból, a többiek Bács-Kiskun, Szabolcs-Szatmár-Bereg, Hajdu-Bihar, Borsod, Fejér, Vas illetve Győr-Moson-Sopron megye városaiból, illetve nem ritkán kisebb falvaiból kerültek ki az európai munkaerőpiacra. A célállomásokat tekintve Németország (München, Frankfurt, Berlin és kisebb települések), Hollandia (Hága, Amsterdam, Rotterdam), Svájc (Zürich, Básel) és természetesen Anglia (London, Oxford és kisebb települések), valamint Franciaország kisebb városai adnak jelenleg otthont az általunk megkérdezett, kivándorolt magyar fiataloknak. Fontosnak tartjuk megjegyezni, hogy bár kutatásunk kezdetén úgy véltük, a mintában felülreprezentáltak lesznek a Londonba és környékére költözött fiatalok, mint már fentebb utaltunk is rá, a válaszadási hajlandóság lényegesen nagyobb volt a német nyelvterületen (Németország, Svájc és környékén, Hollandia) élő magyar fiatalok között. Így a mintában szereplők aránya ezekből az országokból a The Network és Boston Consulting Group által készített felméréssel cseng össze, amely - mint korábban említettük - a Magyarországról választott célországok sorrendjében első helyre tette Németországot, Svájcot (és Ausztriát), azután az Egyesült Államokat, s csak ezek után következik a sorban az Egyesült Királyság. E jelenség valódi okát egyelöre csak feltételezzük.

Végzettségüket tekintve a paletta igen diverzifikált. Többen közgazdász, vagy pénzügyi végzettségüek, de beszélgettünk földmérést végző mérnökkel, gépészmérnökkel, biomérnökkel, vegyészmérnökkel, közlekedésmérnökkel, könyvvizsgálóval, szociológussal, pszichológussal, geográfussal, diplomás szociális munkással és nemzetközi kapcsolatok szakértővel. Egy kivételével mindegyikükre jellemző, hogy a szakmájában helyezkedett el, vagyis végzettségének megfelelö munkát végez. Csaknem mind alkalmazott értelmiségiként, néhányan közülük már középvezetői menedzser szinten dolgoznak. Egyharmaduk szeretne további tanulmányokat folytatni, azonban közülük senki sem jönne haza ezért. Mindegyikük 
külföldön szeretné ezeket a további tanulmányokat elkezdeni, akkor is, ha nem egy továbblépéshez szükséges tanfolyamról, hanem a fizetős mesterképzésről van szó, amelynek költségeit magának a fiatalnak kell - adott esetben -állnia.

Kutatásunk szempontjából lényeges, hogy alap- vagy mesterképzés után vállalt-e munkát külföldön a fiatal és az is, hogy hol végezte a felsőoktatási tanulmányait - itthon, vagy esetleg külföldön. Ebből a szempontból három fő kategóriát állítottunk fel. A „külföldön, itthon illetve vegyesen" kategóriákat, s ezeken belül is alkategóriákat, hiszen a Bsc-, Msc-végzettség is megszerezhető bontásban itthon és külföldön. Ez alapján a következőket mondhatjuk: felmérésünk szerint a mintában szereplök valamivel több, mint 20 százaléka itthon végezte az egyetemi alapképzést, majd a végzés után egyből, vagy kis időre rá külföldre távozott. Valamivel kevesebben, de közel 20 százalékos arányban végezték eleve már az alapképzést is külföldön, közülük néhányan elöször hazatérve próbáltak érvényesülni a kint szerzett diplomával, de a vártnál kisebb siker után ismét másik országban kerestek/keresnek épp állást. Több mint 40 százalékuk itthon fejezte be a mesterképzést is, majd rövidebb-hosszabb idö után, családi okokból (a párjuk már kint dolgozott) vagy elhivatottságból (munkahelyi átszervezések) vagy érvényesülési okokból valahol Európában folytatták. A mintából pedig azok aránya, akik itthon végezték az alapszakot és külföldön a mesterszakot, 25 százalék körüli értéket mutat. Ugyanakkor 10 százalék alatti a mindkét képzést már külföldön végzők aránya. A fennmaradó részt azok töltik ki, akik abban a speciális helyzetben vannak, hogy a PhD-végzettségüket szerezték/szerzik éppen valamelyik európai egyetemen. Közöttük van, aki itthon végezte a mesterszakot is és van, aki azt már a választott külföldi egyetemen.

Az itthon a felsőoktatási intézményekben megszerezhető külföldre szóló ösztöndíjakkal kapcsolatban azért tettünk fel kérdéseket, hogy lássuk, a tanulmányok alatt külföldön végzett szemeszterek mennyiben befolyásolják a későbbi döntést a kiköltözéssel kapcsolatban. Mindent összevéve azt mondhatjuk, hogy a mintában szereplö fiatal felnöttek nem mind vettek részt külföldi tanulmányúton - van a mintában olyan fiatal, aki határozottan elutasította mind az öt év alatt, hogy külföldre menjen huzamosabb időre - azonban minden, ösztöndíjjal külföldet megjárt fiatal rövidebb idön (2-3-éven) belül külföldön keresett és kapott állást s él kint a mai napig. Vagyis abból a szempontból, amelyet dolgozatunk elején említettünk, hogy az Egységes Európai Tanulmányi Térség létrehozói szándékuk szerint Európa munkaerőpiacára képeznék a tehetséges fiatalokat, ennyiben igazolódni látszik. Az más kérdés, hogy ténylegesen hány magyar fiatal él például az Erasmus-ösztöndíj pályázati lehetőségével (a statisztikák szerint a magyar hallgatók mindössze 4 százalékáról beszélünk) hiszen ezek az ösztöndíjak többnyire nem elegendők ahhoz, hogy a diák külföldi tanulmányai alatt a teljes költséget fedezzék, ezért támogatói, vagyis általában szülői háttér függvénye, melyik hallgató foglalkozhat egyáltalán a kiutazás gondolatával.

A válaszadók kétharmada úgy nyilatkozott egyébként, hogy több mint 8 órát dolgozik általában, ezért nem túlórapénzt, hanem több szabadnapot vagy bónuszt kapnak év végén, a közeli barátaik jórészt itthon vannak, külföldön inkább a nemzetközi társasággal (munkahely) járnak kikapcsolódni, illetve természetesen a magyarok „mindenütt megtalálják egymást”. Jelenlegi mintánkban a 28 fiatalból mindössze 2 női válaszadónak volt gyermeke egyiküknek két óvodáskorú, ám ezzel együtt ez a válaszadó a rangidős is (35) az összes megkérdezett között.

\section{Családi háttér}

A családi hátteret vizsgálva a mintában szereplők válaszai alapján számunkra feltünően sokan nőttek fel egyszülős családban. A mintában szereplö fiatalok több mint 40 százaléka elvált szülök gyermeke. A 28 válaszadóból 12-en nyilatkoztak úgy, hogy a szülei elváltak. A szülők iskolai végzettségét tekintve mind az apák, mind az anyák valamivel több mint 50 
százalékban egyetemi, főiskolai végzettséggel rendelkeznek - az anyák esetében ez inkább 60 százalék -, ezen csoportba tartozók közül néhányan tudományos fokozatot is szereztek, valamivel több, mint 30 százalékban a szülők szakközépiskolai érettségivel rendelkeznek, a maradék körülbelül 10 százalék érettségi nélküli szakiskolát vagy nyolc általánost végzett. Az apák foglalkozása szerint körülbelül fele-fele arányban alkalmazásban állók vagy vállalkozók, az anyák több mint 50 százalékban alkalmazásban állók, valamivel több, mint 20 százalékuk vállalkozó, a többiek általában otthon vannak. Érdekes volt látni: ebben a kis mintában is átütö jelenség, hogy a fiatalok szülei közül az elvált anyák voltak/vannak rosszabb helyzetben - mint ahogy azt az egyedül maradt nőkkel kapcsolatban a szakirodalom rendszeresen megemlíti (Vukovich, 1999; Farkas, 2008). Ha volt már a családban valaki munka nélkül, akkor a válaszadók az édesanyát említették jóval nagyobb arányban, vagy jelölték meg jelenleg is betegnek, munkaképtelennek, mint aki a külföldön élő gyermeke segítségére szorul. A válaszadók közel 30 százaléka nyilatkozott úgy, hogy rendszeresen vagy alkalmanként küld haza segítségként pénzt a szüleinek (többnyire az édesanyának), illetve segítette a testvére elindulását ugyancsak valamelyik európai országban.

A válaszadók közel fele itthon, a szülökkel nagyobb (120-150 négyzetméter feletti) házban vagy lakásban lakott, s valamivel kevesebb, mint 30 százalékuk élt kisebb lakásban (panel, 50-70 négyzetméter) vagy házban. A válaszadók csaknem 40 százalékára jellemző volt, hogy a család havi nettó jövedelme a magasabb, 400 ezer forint feletti kategóriába esik - ezen családok egy része akár ennek a jövedelemnek a két-háromszorosával is rendelkezik az élettörténetek szerint -, ennek ellenére százalékosan kimutatható különbség mutatkozik azoknál a válaszadóknál, akik e havi jövedelem alapján érzékelt életminőségüket mégsem a legjobbak között élték meg. Ugyanis annak ellenére, hogy sokszor a család jövedelme magasabbnak mondható a magyar viszonyokat tekintve, s a válaszadók kiválónak vagy jónak élték meg az életszínvonalukat a szülökkel töltött időkben - a középiskola és/vagy az egyetem alatti kollégiumi évekkel együtt -, az esetek nagy részében arról számoltak be a fiatalok, hogy mindez nem jelentette a család számára a „nagy lábon élés” lehetőségét. Nem feltétlen mentek luxus utakra, bár természetesen utaztak, színházba, moziba jártak együtt, rendszeresen. Ezt, a „beosztónak” is nevezhető szemléletet sokan viszik tovább a válaszadó fiatalok közül, az általuk most már megteremetett, s mindenképpen preferált életszínvonal ellenére. Pénzkezelési szokásaik is nagyban változtak, amióta egyedül, de legalábbis a szülőktől távol élnek. Ennek egyik okaként vetjük fel, hogy ezen jó körülmények között felnőtt válaszadók csaknem 20 százaléka nagycsaládban nevelkedett, a testvérek száma 2-3 vagy 4 fö. Jobban ábrázoljuk a helyzetet, ha idézzük a 11. számú (fiú) válaszadónkat, aki, bár fizetős, magán felsőoktatási intézménybe járt, elmondása szerint ettől a család életét nem jellemezte a felesleges költés, hiszen rajta kívül még három lánytestvér volt otthon: „...én 18 -20 éves koromig rendszeresen a Tescóból öltözködtem.”

Ugyanakkor a teljes minta valamivel több, mint 30 százaléka nyilatkozott úgy, hogy a család jövedelme 100 ezer alatt vagy éppen fölötte volt (100-200 között) havonta, közülük mégis nagyobb arányban jó vagy megfelelő színvonalúnak élték meg a szülőkkel közös $s$ az itthon tanulással töltött éveket. Ezt az életutak alapján azzal magyarázzuk, hogy többnyire ezek a válaszadók Magyarországon is a kisebb településeken élö, összetartó, de szolid körülmények kötött levő családokból indultak el. A középiskolai vagy felsőoktatási éveik alatt a kisvárosi kollégiumi élet nem támasztott a megszokottnál magasabb igényeket, ugyanakkor koncentráltan hangsúlyt helyezett a fiatalok tanulmányi előmenetelére. Valamivel több, mint 10 százaléka viszont kifejezetten hangsúlyozta, hogy nem élt jó színvonalon, a családi körülmények nehezítették az életkezdésben és a tanulási lehetőségeiben. 


\section{Néhány ok a külföldi munkavállalásra}

Az elindulás okairól igencsak diverzifikáltak a vélemények, ha az egyéni életutakon keresztül alaposabban szemügyre vesszük a fentebb általunk idézett kutatások ,anyagi okokként" megjelölt, statisztikai terminusait. Mivel a kutatásnak ebben a részében csak részeredményeket tudunk publikálni, így egyelöre ehhez mérten dolgoztuk fel a válaszokban megtalálható okokat:

„Lássuk be, Magyarországon (..) önállósodni sem olyan természetes.” (1 sz. válaszadó - fiú) Nos, e mondatnál plasztikusabban mi magunk sem tudjuk leírni a fiatalok életérzését. Azonban általánosságban azt mondhatjuk, hogy-egy-két „hirtelen ötlettől” vezérelt lépéstől eltekintve - épp az idézett mondat miatt - a mintában szereplö fiatalok egy része vagy tudatosan, az egyetemi tanulmányokat jól felépítetten (itthoni alap-, külföldi mesterképzés, vagy már kint is kezdett), vagy a menet közben megszerzett információk hatására lépett átgondoltan. Ahogy $2 \mathrm{sz}$. válaszadónk (fiú) is fogalmazott: „...az Egon Biztosítónál találtam állást Amszterdamban. Kockázatkezelöként dolgoztam ott. Felvettek, mert megvolt ugyanaz a mester diplomám, mint a helyieknek."

Nos, a többi között ezért is fontos a kutatásban tisztáznunk az itthon, illetve külföldön végzett alap- és mesterképzések arányát. Az eddigi mintában szereplő fiatalok válaszai alapján ugyanis azt mondhatjuk, hogy akik valamelyik - vagy mindkét - diplomájukat már külföldön kapták vagy viszonylag hamar elmennek, vagy vissza sem jönnek. Hiszen azzal, hogy valahol Európában végzik például a mesterképzésüket, lényegesen könnyebb versenybe szállni ugyanazért az állásért.

Ám természetesen van még egy érv, a külföldi munkavállalás mellett, amelyet nem szívesen hagynánk ki a sorból - bár ismét hangsúlyozzuk, hogy a lista még korántsem teljes. Nevezetesen, a hazai diplomás fiatalokat sújtó munkanélküliség, mint az életkezdési esélyeket akadályozó tényező. S bár területfüggő, hogy Magyarországon hol találnak könnyebben állást a fiatalok a végzés után a saját szakmájukban, a gazdaságilag nehéz körzetekben élök esetén kitartó keresgélés után is gyakran két lehetőség adódik: vagy a szakma feladása, vagy persze a megyehatárok, sőt: az országhatár átlépése tünik a legkézenfekvőbb megoldásnak.

\section{A fiatalok lelkiállapotáról}

Az általunk megkérdezett, a mintában szereplö fiatalok csaknem 100 százaléka - közepesen vagy nagyon, de - elégedett a jelenlegi helyzetével, azzal, ahol az élete éppen tart. A „csaknem” általában valamilyen lelki (párkapcsolati, családalapítási, épp szakítási, állásváltási) gondokkal függ össze, mindössze egy válaszadó nyilatkozott úgy, hogy talán a nem megfelelö alapdiploma az, amely miatt nehezebben talál állást az adott országban. Jóllehet ez, a 24. számú válaszadó egy két éves kisgyermek édesanyja, így körülményei is nehezebbek, mint a többi, 93 százalékban gyermektelen fiatalnak. Azonban meglepö, hogy azok a válaszadók is elégedettségnek adtak hangot a jelenlegi helyzetükre vonatkozóan, akiknek itthon, Budapesten saját lakásuk volt, most pedig évek óta albérletet fizetnek a célországban. A mintában szereplök kétharmada kifejezetten sikeresnek ítélte meg az eddigi szakmai életútját - ahhoz képest, mint amit itthon sikerült volna elérniük - nemcsak anyagi téren. A személyiségükkel kapcsolatos válaszokból nominálisan is egyértelmüen kiderül, hogy döntő többségük optimista alkatnak, inkább extrovertált személynek és érzelmileg stabilnak tartja magát, ezen jegyek negatív - komplementer párjait csak néhányan említették. Fele-fele arányban jól, illetve kevésbé jól türik a stresszt, viszont feltűnő, hogy szinte egyformán határozottan állították - kevés kivételtől eltekintve -, hogy szeretnek küzdeni. Mindemellett a függetlenség érzésére egy ötös skálán négyesnél rosszabbat senki sem adott magának. 18-an az 5-ös, 10-en a 4-es mellé tették le a voksukat. S bár a „független” szó 
jelentését a kérdésben nem szükítettük le, az tendenciózusan megfigyelhető, hogy akik 4-est adtak maguknak, azon válaszadók vagy párban élnek jelenleg, vagy nagyon afelé fordult a gondolkodásuk, hogy mihamarabb stabil partnert találjanak maguknak.

\section{Jövedelmi viszonyok - terhek spiráljában}

Az alapdiplomával rendelkező fiatalok, kisebb vagy nagyobb cégeknél, adminisztratív vagy terepmunkát kívánó állásokban, illetve a szociális szférában dolgozók euróban számolva 1500 és 1800 euró közötti fizetésekből élnek - általában párkapcsolat nélkül, többnyire egy szobát bérelve. Külön kategóriát képeznek azonban azok a pénzügyi végzettséggel rendelkezö, általában már mesterdiplomás fiatalok, akik a húszas éveik vége felé, illetve a harmincas éveik elején járnak a mintában, többségük az alapdiplomát itthon szerezte, a mestert már valahol Európában, majd valamelyik nagy - multinacionális - vállalatnál helyezkedtek el. Ezen fiatalok ugyanis - az adott országban szerzett végzettségüknél fogva - mindenképpen a multi környezetnek megfelelő éves fizetést kapják, legyen szó Berlinről, Londonról, Hágáról, Amszterdamról vagy Zürichről. Körükben az évi 50-80 ezer fonttól a 90-120 ezer euróig terjed a jövedelmük. Ök már nem szobát, hanem 2-3 szobás apartmanokat bérelnek, e világvárosok legjobb helyein. Legtöbbjük nem több mint 3-4, esetleg 5 éve ment el Magyarországról (pénzügyi területen a mesterképzés sok helyütt nem kettő, hanem egy erős év).

Azonban éppen azért készítettünk egyéni életút-interjúkat, hogy meglássuk az ide vezető utakban rejlő különbségeket és azonosságokat. Nem állíthatjuk, hogy annak a fiatalnak nem volt könnyebb külföldön végeznie a mesterképzést, akinek a szülei átlag havi 1000-1500 euróval (mert ennyit említettek a fiatalok) hozzájárultak a költségeihez, mint aki az addigi munkáiból tudatosan félretett pénzéből, diákhitelből fedezte a tanulmányait. $\mathrm{S}$ amely hitelt természetesen euróban vett fel - mint konkrét példánk is mutatja - ezek a diákhitelek nem kevesek (35 000 euró például egy spanyolországi egyetem mesterképzése). Európának ezen a részén a felsőoktatási intézmények „nem feltétlen engedik meg maguknak”, hogy addig hitelezzenek a volt diáknak, amíg az megfelelö jövedelemre szert nem tesz ahhoz, hogy a megélhetését ne befolyásolja a részletfizetés. Anglia más gyakorlatot követ - mint erre korábban már utaltunk. S mint 20. számú válaszadónktól megtudtuk, ehhez a diákhitelhez hogy ez „csak ennyi” - maximálisan kellett teljesítenie. Az angol nyelven zajló oktatás minden egyes tárgyában (pénzügy) kiváló minősítéseket kellett szereznie. Úgy vette fel a hitelt, hogy közben kiszámolta, ha végez, mennyi pénzt kell ahhoz keresnie havonta, hogy lakást béreljen valahol, törlesszen, éljen, havi rendszerességgel küldjön haza támogatást a Szabolcsban egyedül élő édesanyjának, néha haza is tudjon jönni, meglátogatni öt is és elvált szülők gyermekeként - a fővárosban élő édesapját és a testvéreit is. Hogy ezt elérje, 20. számú válaszadónk saját bevallása szerint vagy 200 céghez adta be az önéletrajzát a végzéshez közeledve. Ebből 10 megvalósult állásinterjún vett részt, végül három ajánlatból került el Londonba, egy hitelminősítő világcég egyetlen pozíciójába. 20. számú válaszadónk mindehhez 26. életévét tölti. Ilyen körülmények között fel sem vetődhetett, hogy itthon keres állást a diploma után. Teljesen egyértelmü, hogy ezeket a terheket egyetlen, Magyarországon esetlegesen kapott szerződéssel - jövedelemmel - sem tudta volna teljesíteni.

Megfigyeléseink szerint egyébként mindkét csoportra jellemző volt, akár a szülők által támogatottan, akár saját maga által megoldott finanszírozással végezte is el a fiatal külföldön a mesterszakot, hogy kitartóan, az összes megszerezhető képesség birtokában tanultak, tanulnak és dolgoznak. Illetve kevés kivételtől eltekintve általánosságban jellemzően mondhatjuk a mintára, hogy már az alapképzés alatt szinte végig dolgoztak. A szülöi támogatást egyáltalán nem élvező fiatalok - ilyen a minta közel 30 százaléka - a tanulmányi idő alatt is folyamatosan vállalt munkát, annak ellenére, hogy nappali képzésben végezték az 
egyetemet. Illetve természetesen az oktatási szünetekben - itthon és külföldön egyaránt Magyarországon ez diák- vagy alkalmi munkákat jelentett számukra. Ezek az alkalmi munkák - a fiúk esetében - semmiképpen nem kizárólag „fehérgalléros” munkalehetőségeket hozott. Igen kreatívan, a lakóhelyükhöz közeli, például konzervgyári rakodástól a 24 órás éjjelnappali készenlétet kívánó fordítói munkáig, igen széles palettát vonultattak fel a fiatalok a válaszaikban. Fontos megjegyeznünk, hogy egyik válaszadó sem említette, hogy a szülei ösztönzésére vállalta volna a kemény munkákat, vagy egyáltalán a munkákat a szünidőben, vagy az iskola alatt. Mindegyik diák maga szeretette volna megragadni a lehetőséget, vagy azért, mert szüksége volt a zsebpénzre, vagy azért, mert a kitüzött céljaihoz igyekezett a referenciákat gyüjteni. A külföldön a tanulmányok alatt dolgozó fiatal nők általában nagyobb cégek gyakornokaiként dolgoztak, viszonylag kis jövedelemért (800-1000 euró), amelyekböl épphogy csak ki tudtak jönni hó végére. Némelyikük azért hagyott ki időt az alap- és a mesterdiploma között, hogy össze tudja gyüjteni a mestertanulmányok idejére szükséges önellátás feltételeit, mert egy erős, nappali mesterképzés mellett viszont egyáltalán nincs mód munkát vállalni. Legalábbis nem éri meg másra figyelni, mint a tanulásra. Ami viszont egységesen leszürhető ebböl a hozzáállásból: ezek a diákok, akik külföldön is jó állásokban állják meg a helyüket, hozzászoktak a teljesítményorientált gondolkodásmódhoz, nem idegen tölük a kitartást igénylö munka.

Azt is elmondhatjuk a minta alapján, hogy a megkérdezettek itthon, Magyarországon átlag 40-60 ezer forintból gazdálkodtak havonta az alapképzésük idején, vagy kollégiumban, vagy többen szobát bérelve, igen ritkán otthon lakva. Azok is ezt a 60 ezer forintos havi zsebpénzt említették, akiknek esetleg - a családi helyzettől függően - saját lakásuk volt már az egyetem ideje alatt. Ezek a fiatalok - többnyire nők - ugyanis ilyen esetben kiadták a saját lakásuk egyik szobáját vagy „sarkát” egy másik diáktársuknak, így nem egyedül osztoztak a terheken. Ezt tették egyébként azok az extrém helyzetben lévő fiatalok is, ahol a szülö (szülők) korai elhalálozása, illetve a család szétesése miatt egyedül tartották el magukat a fiatal lányok/nők, gyakorlatilag 14-16 éves koruk óta (a havi árvasági segély járt). Ezért ezeknek a fiataloknak létkérdés volt, hogy az egyetem alatt rendszeresen dolgoznak, azonban ezen diákok extrém teljesítményt is képesek voltak nyújtani az egyetemen ahhoz, hogy a maximális ösztöndíj és számos más, pályázat útján megszerezhető jövedelmük legyen.

Ilyen kitartó szorgalom és nehéz családi viszonyok után talán nem is csoda, hogy szüknek bizonyultak a lehetőségek itthon és elindultak - történetesen már közgazda alap-/mesterdiplomával a zsebükben - Európába.

A státuszszerzési helyzeteket illetően a válaszadók körülbelül 85 százaléka válaszolta azt, hogy lényegesen jobb a helyzete, mintha itthon élne, dolgozna, és akarna továbblépni. A kinti jövedelemből általában albérletre, az életre, utazásra és némi megtakarításra is jut, bár ez terhektöl és igényektől függően természetesen változó.

A jelenlegi válaszadók közül körülbelül 15 százalék az, akinek a státusza nem jobb, inkább egyenlö azzal, mintha itthon maradt volna - különösen a pénzügyi területen elhelyezkedök nyilatkoztak úgy, hogy itthon is jóval az átlag fölött lenne a fizetésük. Azonban mindegyikük jobban érzi magát, mintha Magyarországon lenne hasonló helyzetben, ennek okaként a munkahelyi környezetet és az emberek közötti viselkedési szabályok tiszteletben tartását, az egymáshoz való hozzáállást említették, amelyet a jelenlegi helyzetükben lényegesen elfogadhatóbbnak tartanak, összehasonlítva az itthon szerzett esetleges munkatapasztalatokkal, élményekkel. Az életminőségükhöz viszont - saját bevallásuk szerint - kifejezetten hozzájárulnak a kinti kapcsolati és munkahelyi élmények, amelyekről a minta több mint egyharmadának volt már itthon negatív tapasztalata. 


\section{Konklúzió}

A társadalmi mobilitás kutatás egyik klasszikusára, Sorokinra hivatkozva, Róbert Péter a demokratikus társadalmak teoretikus szabályai szerint müködő nyitott társadalomról szólva azt írja, hogy az egyén társadalmi pozícióját nem a születés határozza meg, hanem a nyitott pozíciókkal kecsegtető lehetőségek, hiszen az egyén szabadsága és függetlensége, mint legfőbb érték jelenik meg, és a megengedő szemlélet szerint „mindenki azzá válhat, amivé a képességei teszik" (laissez-faire). A társadalmi mobilitás értéke és értelme funkcionalista alapok szerint viszont megközelíthető úgy is, hogy a gyermekek különböző státuszú (foglalkozás, iskolázottság, vagyoni helyzet) családokba születnek bele, miközben - ettöl függetlenül - a tehetségek és képességek feltehetően egyenletes eloszlást mutatnak egy társadalmon belül. A mobilitás tehát mintegy „korrigálja” a származási különbségeket azzal, hogy különböző szürők segítségével mindenki arra a helyre kerül, ahol a társadalom számára a leghasznosabb. Fentebb hosszan leírt saját, folyamatban lévő kutatásunk részeredményei és az említett statisztikákat összegző vizsgálatok tükrében joggal tehetjük fel a kérdést - vajon melyik társadalom hasznára lesznek éppen a külföldre távozott diplomás fiatalok, akiknek jelentős része egyedülálló nő? $\mathrm{S}$ ha az egyetemisták nagy többségére igaz is az a Hrubos-féle megállapítás, hogy az alap- és mesterképzés lépcsője szürőhatásként érvényesül, különösen a fizetős szakok bevezetése óta, a kis mintánkban szereplő életutak mégis azt bizonyítják, a tehetséges kivételek mégsem a szürőhatás íratlan szabályát erősítik. Saját kutatásunk eddigi eredményei alapján általánosságban elmondhatjuk, hogy azok a diákok, akik külföldön is jó állásokban állják meg a helyüket, hozzászoktak a teljesítményorientált gondolkodásmódhoz, felelősségtudatuk igen fejlett az itthon maradt, esetlegesen rászoruló családtagok támogatását illetően, vagy/illetve az őket a tanulásuk alatt jelentős mértékben támogató szülők felé. A minta közel kilencven százalékában erős a kötődés az itthoni családtagokhoz, ez a gyakori, általában heti egy-két - nem ritkán napi - kapcsolattartási szokásokból könnyen leszürhető. Ugyanakkor nyitottságuk, nagy többségében optimista szemléletük és saját bevallásuk szerint nagyobb számban extrovertált személyiségük, minden feladatot megoldani vágyó küzdési hajlamuk alkalmassá teszi öket arra, hogy ne csak Magyarország kisebb, ám szükebb munkaeröpiacán, hanem a nagyobb, ám lényegesen több lehetőséget nyújtó európai munkaerőpiacon is sikeresek legyenek. Ennél fogva tehát mintánkban is alig néhány fiatal válaszolta kérdésünkre azt, hogy belátható időn belül - vagy bármikor a jövőben - hazatérne.

\section{Irodalom}

Balogh, L. (2006): A tehetséggondozás pszichológiája Alkalmazott pszichológia. 33-49.

Bodnár, G., Takács, I., Balogh, Á. (2011): Tehetségmenedzsment a felsőoktatásban. Kiadó: Magyar Tehetségsegítő Szervezetek Szövetsége. Letöltés: 2015. október 26. Web: http://tehetseg.hu/sites/default/files/19_kotet_net.pdf\#page=11

Bondzsér, Z.(2012): Kollégiumok szerepe, helye a magyar közoktatás és szakképzés rendszerében Tehetségfejlesztés tehetséggondozás feladatok, lehetöségek.Letöltés: 2015.október 26. Web: http://www.fovpi.hu/data/cms149065/Bondzser_Zita.pdf

Czeizel, E. (2003): Legnagyobb természeti kincsünk: a tehetség Fizikai Szemle 2003/11, Letöltés: 2015. október 26. Web: http://fizikaiszemle.hu/archivum/fsz0311/c zeizel0311.html

Farkas, Sz. (2008): Néhány információ az egyszülős családokról. TÁRKI, Letöltés: 2015. november 1.web: file:///C:/Users/edit/Downloads/farkaszs_egyszulos_csaladok_2008.pdf

Gazsó, T. (2012) Munkaerő - piaci helyzetkép. Magyar Ifjúság. 127-152.

Gábor, K., Szemerszki, M., Tomasz, G.(2006): A kétciklusú képzés kezdetei; FKI; Budapest.

Gömöry, K. (2010): Az iskolai tehetségfejlesztés pszichológiai háttértényezöinek vizsgálata felső tagozatos korban Letöltés: 2015. október 26. Web: https://dea.lib.unideb.hu/dea/ 
bitstream/handle/2437/104992/G\%C3\%B6m\%C3\%B6ry\%20Korn\%C3\%A9lia\%20-\%20\% C3\%A9rtekez\%C3\%A9s-t.pdf?sequence=7\&isAllowed=y

Hrubos, I.(2012): A társadalmi esélyegyenlőtlenségek új színterei a felsőoktatásban. Iskolakultúra, 2012/1-2; Letöltés: 2015. október 30. Web: file:///C:/Users/edit/Downloads/ korrekt\%C3\%BAra.pdf

Róbert, P. (2001): Hipotézisek az oktatás és a társadalmi mobilitás összefüggéseiről. Társadalmi mobilitás,2001, 1 156-164.

Róbert, P. (1990): Társadalmi mobilitás; Társadalmi Riport 1990. Szerk.: Andorka - KolosiVukovich; 356-372.

Ruff, T. (2013): Ifjúsági mobilitás: hajlandóság, lehetőségek és tervek in: Magyar Ifjúság Tanulmánykötet 2012 Letöltés: 2015. október 30. Web:http://kutatopont.hu/files/2013/09/ Magyar_Ifjusag_2012_tanulmanykotet.pdf

Ságvári, B.(2012): Az átmenetek kora?- A magyar fiatalok társadalomképéről, in: Társadalmi integráció a jelenkori Magyarországon, Tanulmányok; MTA Társadalomtudományi Kutatóközpont (Szociológiai Intézet), Argumentum Kiadó; p. 63-82.

Teichler, U.(2011): A hallgatói mobilitás esete a Bolognai folyamattal Letöltés: 2015. október 30. Web: http://epa.oszk.hu/01500/01551/00058/pdf/educatio_EPA01551_201104_tan5.pdf

Utasi, Á.(2002): Társadalmi integráció és családi szolidaritás. Educatio 2002/3 (384-404. pp) Letöltés: 2015. október 31. Web: file:///C:/Users/edit/Downloads/2002_3_ tan_UA\%20(2).pdf

Veroszta, Zs. (2013). Letöltés: 2015.10.10. Web: www.felvi.hu/pub_bin/dload/ frissdiplomasok2011.../veroszta.pptx

Vukovich, G.(1999): Egyedülálló szülők és gyermeküket egyedül nevelő szülők. Letöltés: 2015. november 1. Web: http://www.tarki.hu/adatbank-h/kutjel/html/a615/

\section{Internetes hivatkozások}

Net 1: Tehetséges fiatalok menedzselése a felsőoktatási intézményekben Letöltés: 2015. október 26. Web: http://tehetseg.hu/sites/default/files/19_kotet_net.pdf\#page=11

Net 2: Ponthatárok, statisztikák, rangsorok Letöltés: 2015.október 26. Web: http://www.felvi.hu/felveteli/ponthatarok_rangsorok

Net 3: Decodig global talent Letöltés: 2015.oktober 29. Web:https://www.bcgperspectives. com/content/articles/human_resources_leadership_decoding_global_talent/

Net 4: Miért indulnak útnak a magyarok Letöltés: 2015.oktober 29. Web: http://hataratkelo.blog.hu/2015/10/13/miert_indulnak_utnak_a_magyarok

Net 5: Az ország gerince megy el Letöltés: 2015.oktober 29. Web: http://hataratkelo.blog. hu/2014/06/05/az_orszag_gerince_megy_el 